\title{
External benefit and external cost in the economics agroforestry systems in north western parts of Tamil Nadu
}

\begin{abstract}
Agroforestry is defined as a dynamic, ecologically based, natural resource management system that, through the integration of trees on farms and in the agricultural landscape, diversifies and sustains production for increased social, economic and environmental benefits for land users at all levels (Leakey, 1996). Agroforestry has considerable potential to contribute towards solving some of these problems. Nitrogen-fixing trees, as substitutes or complements for chemical fertilizer, can increase smallholder incomes, conserve foreign exchange and improve regional food security. By providing a supply of fuelwood from the farm, agroforestry can help reduce pressure on forests and communal woodlands. Moreover, agroforestry trees can supply farm households with a wide range of other products, including food, medicine, livestock feed, and timber for home use and sale. Other services that trees provide, such as boundary markers, windbreaks, soil erosion barriers, beauty and shade, are difficult to quantify but are none the less of substantial importance to farm families and for natural resource protection. The present study is the outcome of socio-economic diagnosis of traditional as well as commercial agroforestry practices followed by farmers in north western parts of Tamil Nadu. Tree species like Texctona grandis, Tamarindius indicus, Casuarina equestifolia and Eucalyptus spp. were dominant species in traditional system whereas, Texctona grandis and Tamarindius indicus were the main species of commercial agroforestry. The net return from tree produce ha ${ }^{-1}$ per annum in commercial agroforestry system was Rs. 432773, Rs. 886711, Rs. 457998 and Rs. 908226, respectively for Teak growers, Tamarind growers, teak + maize and tamarind + sorghum, respectively. In commercial agroforestry, B:C ratio has been found higher (6.59) for tree based crop than tree crop (5.90). Although traditional agroforestry seems less promising as compared to commercial agroforestry, but it is also relevant to the farmers livelihood.
\end{abstract}

KEY WORDS : Agroforestry, Social cost, Social benefit, Socio-economic analysis

How to cite this paper : Sangeetha, R. and Shanmugam, T.R. (2015). External benefit and external cost in the economics agroforestry systems in north western parts of Tamil Nadu. Internat. J. Com. \& Bus. Manage, 8(1) : 28-35.

\section{MEMBERS OF THE RESEARCH FORUM}

Correspondence to:

R. SANGEETHA, Department of Agricultural Economics, Tamil Nadu Agricultural University, COIMBATORE (T.N.) INDIA

Email: sangeethaagri@live.in

\section{Authors' affiliations:}

T.R. SHANMUGAM, Department of Agricultural Economics, Tamil Nadu Agricultural University, COIMBATORE (T.N.) INDIA

Email: trspragathee@yahoo.com 